\title{
Influencia de taninos sobre características físicas y sensoriales de carne de bovinos en engorda
}

\section{Influence of tannins on the physical and sensory attributes of meat from feedlot cattle}

\author{
Briceida Ortiz-Lópeza, María Antonia Mariezcurrena-Berasaína Rubén Barajas-Cruzb, \\ Patricia López-Pereaa, Héctor Bernardo Escalona-Buendíac J osé Luis Borquez-Gasteluma, \\ María Dolores Mariezcurrena-Berasaína
}

\begin{abstract}
RESUMEN
Para evaluar la adición de $\mathbf{0 . 3} \%$ extracto de taninos en las características físicas y sensoriales de la carne de bovinos engordados de forma intensiva, se utilizaron muestras del músculo Longissimus dorsi de 16 toretes (Bos taurus $x$ Bos indicus), los cuales durante los últimos 70 días de la engorda recibieron dieta de finalización (13.3\% PC y 2.0 Mcal ENm/ kg de MS), y en grupos de ocho se asignaron al azar para recibir uno de dos tratamientos: 1) dieta de finalización (testigo); 2) testigo más $0.3 \%$ (base seca) de extracto de taninos (ET). El extracto de taninos fue de Bypro ${ }^{\circledR}$ (SilvaFeed, I ndunor, S.A., Argentina) que contiene $70 \%$ de taninos. Los toretes se sacrificaron en la planta TIF No. 99. A las $24 \mathrm{~h}$ posteriores al sacrificio se tomaron cuatro muestras $\left(2.5 \mathrm{~cm}\right.$ de grosor) a la altura de la $12^{\mathrm{a}}$ y $13^{a}$ costilla de la media canal izquierda. Se evaluaron las características físicas y el perfil sensorial, así como la percepción y aceptación de la carne por consumidores. Los taninos no influyeron en las características físicas de la carne $(P>0.05)$. El perfil sensorial no fue influenciado por tratamientos $(P>0.05)$. La percepción y preferencia del producto respecto a jugosidad y terneza fue similar para ambos tratamientos. Los consumidores mostraron preferencia por el nivel "Gusta moderadamente", para testigo y tratamiento. Se concluye que la adición de $0.3 \%$ de extracto de taninos en la dieta de bovinos en engorda intensiva, no afecta las características físicas y sensoriales de la carne.
\end{abstract}

PALABRAS CLAVE: Taninos, Carne de bovino, Características físicas, Perfil sensorial.

\begin{abstract}
The aim was to evaluate the addition of $0.3 \%$ of tannins extract on physical and sensory characteristics of meat from cattle fattened intensively. Samples of Longissimus dorsi muscle from 16 bulls (Bos Taurus $x$ Bos indicus), that for the last $70 \mathrm{~d}$ of fattening received a finishing diet (13.3 \% CP and $2.0 \mathrm{Mcal} \mathrm{NEm} / \mathrm{kg} \mathrm{DM})$, in groups of eight were randomized assigned to receive one of two treatments: 1) Finishing diet (CTRL); and 2) CTRL plus $0.3 \%$ (DM basis) of tannins extract (TE). The tannins extract was from Bypro ${ }^{\circledR}$ (Silvafeed, I ndunor, S.A., Argentina) containing $70 \%$ of tannins. The bulls were slaughtered in a TIF plant No. 99. At $24 \mathrm{~h}$ post-slaughter four samples (2.5 cm thick) were taken at the level of the 12th and 13th rib of the left middle carcass. Physical characteristics and sensory profile, as well as, the perception and acceptance of the meat by consumers were evaluated. Tannins did not influence the physical characteristics of the meat $(P>0.05)$. The sensory profile was not influenced by treatments $(P>0.05)$. The perception and preference regarding juiciness and tenderness was similar for both treatments. Consumers showed a preference for the level "Like moderately". It is concluded that the addition of $0.3 \%$ of tannins extracts in the diet of cattle fattened intensively, did not modify the physical and sensory characteristics of meat.
\end{abstract}

KEY WORDS: Tannins, Beef, Physical characteristics, Sensory profile.

Recibido el 2 de marzo de 2015. Aceptado el 23 de abril de 2015.

a Universidad Autónoma del Estado de México, Toluca, Estado de México, México. nekkane16@hotmail.com. Correspondencia al último autor.

b FMVZ-Universidad Autónoma de Sinaloa. Culiacán, Sinaloa, México.

c Universidad Autónoma Metropolitana. México. 


\section{INTRODUCCIÓN}

La calidad de un alimento está determinada por diversos aspectos como cantidad y calidad de nutrientes y la seguridad sanitaria, entre otros; sin embargo, lo que determina la aceptación o rechazo del mismo está relacionado con la percepción del consumidor, es decir, aspectos ligados a la preferencia del color, sabor, textura, consistencia, presentación y otros aspectos del producto(1). En la evaluación de calidad de carne los parámetros más considerados son: apariencia, jugosidad, terneza y sabor(2). La textura, lleva consigo dos componentes principales: terneza y jugosidad, que explican el 64.0 y el $19.0 \%$ respectivamente, de las diferencias entre la apetencia de las muestras(3); la evaluación de la terneza define la aceptación de la carne por parte del consumidor $(4,5)$.

Otros factores que influyen directamente en la terneza y jugosidad de la carne son el contenido de grasa intramuscular $(6,7)$; la densidad de fibra del musculo; cantidad, tipo y disposición del tejido conectivo (relacionado con la genética, sexo, peso y edad al sacrificio, alimentación, uso de aditivos, estrés animal, condiciones de faena, manejo de cadena fría) y tipo de corte asociado al músculo involucrado $(3,8)$.

Los metabolitos secundarios de las plantas como los taninos (condensados e hidrolizables), son utilizados de manera extensa por su potencial para modular la fermentación ruminal e incrementar la utilización de nutrientes en rumiantes $(9)$; estos compuestos añadidos en bajas concentraciones en la dieta pueden generar efectos benéficos, ya que se unen a las proteínas y las protegen de una inmediata degradación, regulando la velocidad de liberación de nitrógeno en el rumen $(10,11)$ incrementando el flujo de aminoácidos esenciales hacia el intestino delgado(11), a lo que se atribuye un mejor desempeño productivo del animal( 12,13$)$. Sin embargo, los reportes en la literatura de la vía de absorción o eliminación de los taninos no son muy claros y por tanto se desconoce si hay acumulación en tejido, o si provocan algún

\section{INTRODUCTION}

The food quality is determined by various aspects such as amount and quality of nutrients and health security, among others. However, what also determines the acceptance or rejection of a food is related to the perception of the consumer, i.e., aspects linked to the preference of the color, taste, texture, consistency, presentation and other aspects of the product(1). In the evaluation of meat quality parameters most considered are: appearance, juiciness, tenderness and flavor(2). Texture, has two main components: tenderness and juiciness, explaining the 64.0 and the $19.0 \%$ respectively, of the differences among the appetence of samples(3); the evaluation of tenderness defined acceptance of meat by consumers $(4,5)$.

Other factors directly influencing the tenderness and juiciness of meat are: the content of intramuscular fat $(6,7)$; the density of the muscle fiber; number, type and arrangement of connective tissue (related to genetics, sex, weight and age to slaughter, feeding, use of additives, animal stress, work, management of cold chain conditions) and type of cut associated with the involved muscle $(3,8)$.

Secondary metabolites of plants such as tannins (condensed and hydrolysable), are used extensively for its potential to modulate the rumen fermentation and increase nutrients utilization in ruminants(9). These compounds added in low concentrations in the diet can produce beneficial effects, since they bind to proteins and protect them from immediate degradation, regulating the release rate of nitrogen in the rumen $(10,11)$, increasing the flow of essential amino acids to the small intestine(11), which is attributed to a better productive performance of the animal( 12,13$)$. However, the reports in the literature of the path of absorption or elimination of the tannins are not very clear and therefore it is unknown if there is tissue buildup, or if they cause any changes in the muscle structure that affect the sensory characteristics of the meat. Therefore, the objective of the present study was to 
cambio en la estructura muscular que llegue a afectar las características sensoriales de la carne. Por lo anterior el objetivo del presente trabajo fue evaluar la adición de $0.3 \%$ de extracto de taninos sobre las características físicas y atributos sensoriales en la carne de bovinos engordados de forma intensiva.

\section{MATERIAL Y MÉTODOS}

\section{Obtención de muestras}

Se utilizaron muestras del músculo Longissimus dorsi de 16 toretes, engordados de forma intensiva en la Unidad Experimental para Bovinos de la Facultad de Medicina Veterinaria y Zootecnia de la Universidad Autónoma de Sinaloa, con una carga génica aproximada de 75.0 \% Brahman y el resto de razas Simmental, Pardo Suizo, Charolais y Angus en proporción variable, con peso corporal promedio de $422 \pm$ $6.7 \mathrm{~kg}$. Los toretes se sometieron al manejo productivo para fase de finalización, que consistió en la aplicación vía subcutánea en la base de la oreja, de un segundo implante a base de acetato de trembolona y 17- $\beta$ estradiol (Component TES con Tylan; ELANCO ${ }^{\circledR}$ ). Durante los últimos 30 días todos los animales además, recibieron $0.15 \mathrm{mg} / \mathrm{kg}$ de dorhidrato de zilpaterol (Zilmax; Lab Intervet - MSD ${ }^{\circledR}$ ), mismo que se suspendió tres días antes del faenado. Los bovinos se asignaron de forma aleatoria a grupos de ocho animales y se alojaron en corrales para recibir uno de dos tratamientos: 1) dieta de finalización (13.3 \% PC y 2.0 Mcal $\mathrm{ENm} / \mathrm{kg}$ de MS) durante los últimos 70 días de la engorda (testigo); 2) dieta testigo más $0.3 \%$ de extracto de taninos (ET). El extracto fue de taninos condensados de quebracho (Shinopsis ssp) que contiene $700 \mathrm{~g} / \mathrm{kg}$ MS (Bypro ${ }^{\circledR}$ SilvaFeed, Indunor, S.A.; Buenos Aires, Argentina).

Los bovinos se faenaron en la planta TIF No. 99. Las canales se colocaron en un cuarto frío a $4{ }^{\circ} \mathrm{C}$, y $24 \mathrm{~h}$ después se realizó un corte transversal en el lado izquierdo de la canal entre la 12. a y 13. a costilla; en el área del ojo de chuleta se midió por triplicado el pH con un evaluate the addition of $0.3 \%$ tannins extract on the physical properties and sensory attributes in the meat of feedlot cattle.

\section{MATERIAL AND METHODS}

Samples

Samples of Longissimus dorsi muscle from 16 steers fattened intensively in the Experimental unit for cattle of the Facultad de Medicina Veterinaria y Zootecnia of the Universidad Autónoma de Sinaloa, with a gene load of approximately $75.0 \%$ Brahman and remainder of Simmental, Brown Swiss, Charolais and Angus in variable proportion, with an average body weight of $422 \pm 6.7 \mathrm{~kg}$. The bulls were subjected to production management for a finishing phase, which consisted of subcutaneous application at the base of the ear, of a second trenbolone acetate implant and 17- $\beta$ estradiol (Component TES with Tylan; ELANCO ${ }^{\circledR}$ ). During the last $30 \mathrm{~d}$, all animals received in addition, $0.15 \mathrm{mg} / \mathrm{kg}$ of zilpaterol hydrochloride; (Zlmax; Lab Intervet - MSD $\left.{ }^{\circledR}\right)$, same that was suspended $3 \mathrm{~d}$ before slaughter. The cattle were assigned randomly to groups of eight animals and were housed in pens to receive one of two treatments: 1) Finishing diet (13.3\% crude protein and 2.0 Mcal ENm/ $\mathrm{kg}$ dry matter) the last $70 \mathrm{~d}$ of fattening (Control); 2) Control diet plus $0.3 \%$ of tannins extract (ET). Tannin extract was of condensed tannins from quebracho (Shinopsis ssp) containing $700 \mathrm{~g} / \mathrm{kg}$ DM (Bypro® SilvaFeed, Indunor, SA; Buenos Aires, Argentina).

Slaughter was done at the abattoir TIF No. 99. The carcasses were placed in a cold room at 4 ${ }^{\circ} \mathrm{C}$, and $24 \mathrm{~h}$ later held a cross section in the left side of the carcass between the 12th and 13th rib. In the area of the rib eye $\mathrm{pH}$ was measured in triplicate with a potentiometer ( HI 99163 membrane pH - meter, Hanna Instruments, USA), equipped with penetration electrode. Consecutively four $2.5 \mathrm{~cm}$ thick samples of the Longissimus dorsi muscle were taken; a portion of $2 \mathrm{~cm}^{2}$, placed in airtight bag previously identified and immediately water 
potenciómetro (HI)9163 membrane pH-meter, Hanna Instruments, EUA), equipado con electrodo de penetración. Consecutivamente se tomaron cuatro muestras del músculo Longissimus dorsi de $2.5 \mathrm{~cm}$ de espesor; de una muestra se tomó una porción de $2 \mathrm{~cm}^{2}$, se colocó en bolsa de cierre hermético previamente identificada y se midió de manera inmediata la capacidad de retención de agua; el resto de las muestras se empacaron al vacío y se colocaron en congelador a -20 o C hasta su uso en las determinaciones físicas y sensoriales.

\section{Medición de características físicas}

Para determinar la capacidad de retención de agua (CRA), se consideró el fluido liberado al aplicar presiones externas. Se pesaron $0.3 \pm$ $0.05 \mathrm{~g}$ de carne, colocándose dentro de un papel filtro, entre dos placas de vidrio, y se sometió a compresión con una pesa de 2.250 $\mathrm{kg}$ durante $5 \mathrm{~min}$. La CRA se calculó por diferencia del peso inicial y el peso final, considerando el porcentaje de jugo liberado(14).

Previo a las determinaciones físicas y sensoriales, la carne se descongeló en refrigeración a 4 ㄷ por $24 \mathrm{~h}$. Las muestras de carne se prepararon de acuerdo al protocolo de "Research guidelanes for cookery, sensory evaluation and instrumental tenderness measurements of fresh meat"(15); éstas fueron desprovistas de hueso y pesadas antes del cocinado en parrilla eléctrica doble (Mod. GRP4P-AR George Foreman ${ }^{\circledR}$ Grill, Miramar, FL, EUA). Se usó un termopar (Hanna Instrument ${ }^{\circledR}$, EUA), para monitorear la temperatura a $70 \pm 2{ }^{\circ} \mathrm{C}$, éste se insertó en el centro geométrico de la muestra, la cual una vez cocinada se dejó enfriar por un periodo de $30 \mathrm{~min}$, se pesó para calcular pérdida por cocción, expresándose como porcentaje de la pérdida de peso respecto al peso de la muestra cruda(14). Posterior al pesaje, de cada muestra de carne se extrajeron 10 cilindros de $1.6 \mathrm{~cm}$ de diámetro, los cuales se obtuvieron insertando un sacabocados de forma paralela a la dirección de las fibras musculares; para determinar la retention capacity (WRC) was measured; the rest of the samples were vacuum packaged and frozen at $-20{ }^{\circ} \mathrm{C}$ until be used for sensory and physical determinations.

Measurement of physical properties

The released fluid by applying external pressure, determined the WRC, weighting $0.3 \pm 0.05 \mathrm{~g}$ of meat, standing inside a paper filter, between two glass plates, and subjected to compression with a weight of 2,250 kg for $5 \mathrm{~min}$. The WRC was calculated by difference of initial weight and final weight, considering the percentage of juice released(14). Prior to the sensory and physical determinations, meat was thawed under refrigeration at $4{ }^{\circ} \mathrm{C}$ for $24 \mathrm{~h}$. The samples were prepared according to the protocol of "Research Guidelines for Cookery, Sensory Evaluation and Instrumental Tenderness Measurements of Fresh Meat"(15); these were devoid of bone and weighted before cooking in an electric double grill (Mod. GRP4P-ar George Foreman ${ }^{\circledR}$ Grill, Miramar, FL, USA). It was used a thermocouple (Hanna Instrument ${ }^{\circledR}$ ), to monitor the temperature at $70 \pm 2{ }^{\circ} \mathrm{C}$, this was inserted in the geometric center of the sample. Once cooked, it was left to cool for a period of 30 min, weighted to calculate loss by cooking, expressed as a percentage of weight loss with respect to the weight of the raw sample(14). After weighting, from each meat sample 10 cylinders of $1.6 \mathrm{~cm}$ in diameter, were obtained by inserting a punch parallel to the direction of the muscle fibers; to determine the shear force (16), each cylinder was placed perpendicular to the Warner-Bratzler blade equipment (Mod. KS 66502 Salter ${ }^{\circledR}$, Manhattan, USA). The results of the physical characteristics of the meat, were analyzed through variance for a completely random design accepting differences with a level of probability $<0.05(17)$, through the use of the computer package Statistix ${ }^{\circledR}$, version 9.0(18).

Sensory profiles measurements

Two complementary experiments were carried out. Samples were prepared following the protocol described for shear force evaluation. 
fuerza de corte(16), cada cilindro se colocó de forma perpendicular a la cuchilla Warner-Bratzler de un equipo Mod. KS 66502 Salter ${ }^{\circledR}$, Manhattan, EUA. Los resultados obtenidos de las características físicas de la carne, se analizaron por medio de varianza para un diseño completamente al azar aceptando diferencias estadísticas con un nivel de probabilidad $<0.05(17)$, mediante el uso del paquete computacional Statistix ${ }^{\circledR}$ (2007), versión 9.0(18).

Medición de atributos sensoriales

Se realizaron dos experimentos complementarios. Para la preparación de las muestras se siguió el protocolo descrito en evaluación de fuerza de corte. Posterior al cocinado, las muestras de carne se cortaron en trozos de 1 $\mathrm{cm}^{3}$, se colocaron en vasos de plástico No. 0 , previamente rotulados con clave de tres números aleatorios; para evitar la desecación antes de ser ofrecidas a los panelistas se ubicaron en un recipiente sellado a $40{ }^{\circ} \mathrm{C}$.

En todas las pruebas sensoriales se ofreció a los panelistas agua y galletas integrales tipo habaneras, y se les solicitó que ingirieran una porción antes y entre muestras con la finalidad de remover los sabores de la boca(19).

\section{Experimento 1}

Se realizó la descripción de las propiedades sensoriales de la carne, y se midió la intensidad percibida por un panel previamente entrenado, conformado por 14 voluntarios (ocho mujeres y seis hombres; 30 a 40 años), estudiantes y académicos quienes trabajaban en el área de Ciencia y Tecnología de Carne. Para el entrenamiento se utilizaron diapositivas, explicación oral y se realizaron ensayos previos con carne de bovino para garantizar que el panelista identificara los descriptores y el uso de la escala(19).

Los panelistas, eligieron por consenso el perfil de los descriptores que proporcionaron información sobre las características de la carne,
After cooking the meat samples were cut into $1 \mathrm{~cm}^{3}$ pieces, were placed in No. 0 plastic cups, previously labeled with three random number key. To avoid drying out before being offered to the panelists, samples were kept in a container sealed to $40{ }^{\circ} \mathrm{C}$. In all sensory tests panelist were offered water and crackers and asked they to eat a portion before and between samples with the aim of removing the flavors of the mouth(19).

\section{Experiment 1}

It describes the sensory properties of the meat, and measured the intensity perceived by a panel previously coached, consisting of 14 volunteers (eight women and six men; 30 to $40 \mathrm{yr}$ old), students and academics who worked in the Meat Science and Technology area. Slides, and oral explanation were used for training and previous tests with beef were carried out to ensure that the panelist identified the descriptors and the use of the scale(19).

The panelists, after bibliographic review, elected by consensus the descriptors profile that provided information on the meat characteristics(20-23). A descriptive quantitative test $(24,25)$ was performed, where panelist scored in a nine-point structured scale the intensity of the evaluated attribute, considering one as the value of less intensity. The results obtained were analyzed with the Wilcoxon signed-rank test, accepting statistical difference of $\mathrm{P}<0.05(24,26)$. The results are presented in Table 1.

\section{Experiment 2}

Characteristics of the consumer panel. To perform the tests: Duo-trio, preference of pairs for juiciness and tenderness, as well as acceptance testing, 88 volunteers intervened, students from the faculties of Veterinary Medicine and Animal Hsbandry and Agricultural Sciences of the Universidad Autonoma del Estado de Mexico. The personal data collected indicated that $49 \%$ were men and $51 \%$ women, aged 19 to $27 \mathrm{yr} ; 43 \%$ said consuming beef more than two times a week, $34 \%$ once 
previa revisión bibliográfica(20-23). Se realizó una prueba descriptiva cuantitativa $(24,25)$, donde el panelista marcó en una escala estructurada de nueve puntos la intensidad del atributo evaluado, y se consideró el uno como el valor de menor intensidad. Los resultados obtenidos se analizaron con la prueba de jerarquía signada de Wilcoxon, aceptando diferencia estadística a $\mathrm{P}<0.05(24,26)$. Los resultados se presentan en el Cuadro 1.

\section{Experimento 2}

Características del panel de consumidores. Para realizar las pruebas: Dúo-trío, preferencia por pares para jugosidad y terneza, así como la prueba de aceptación, participaron 88 voluntarios, estudiantes de las Facultades de Medicina Veterinaria y Zootecnia y Ciencias Agrícolas de la Universidad Autónoma del Estado de México. Los datos personales recabados indicaron que, $49 \%$ fueron hombres y $51 \%$ mujeres, entre 19 y 27 años; 43 \% afirmó a week, $14 \%$ once every $15 d$, while $9 \%$ once a month. They reported that their way of habitual meat consumption was: roast, burgers and stews.

Experimental development. Test Duo-trio(27) was conducted to determine if the meat under assessment was perceived similarly by the consumer. Two triads ( $A-R E F A B$ and - REF BA) were used where $A$ corresponded to the meat sample (control), which was used as a constant reference (REF) and (B) corresponded to the meat sample obtained from fed-tannins animal (ET). Three meat samples were offered to the panelists, one of them marked with the letter " $R$ " reference sample, while the other two were encoded with a random three-digit number. The panelist identified which one of the samples was equal to $R$. The results obtained, were analyzed according to the standard BS ISO 10399:2004, "Sensory analysis-MethodologyDuo-trio test"(27).

Cuadro 1. Descriptores de las características de carne elegidas por los panelistas

Table 1. Descriptors of the characteristics of meat chosen by panelists

\begin{tabular}{|c|c|c|c|}
\hline Atributte & Scale & Definition & Technique \\
\hline \multicolumn{4}{|l|}{ Smell: } \\
\hline Blood & Soft to intense & Blood smell quantification & $\begin{array}{l}\text { Assessed, approaching the } \\
\text { meat } 2 \mathrm{~cm} \text { from the nose } \\
\text { for a period of } 5 \mathrm{sec}\end{array}$ \\
\hline Toasted & Soft to intense & $\begin{array}{l}\text { Aromatic associated with meat after keeping it at } 100{ }^{\circ} \mathrm{C} \\
\text { for } 15 \mathrm{~min}\end{array}$ & \\
\hline Boiled meat & Soft to intense & Aromatic associated with meat when it is boiled in water & \\
\hline Green & Soft to intense & Aromas associated with plants or plant material & \\
\hline \multicolumn{4}{|l|}{ Taste: } \\
\hline Salty & Soft to intense & Flavor that provides sodium chloride & Evaluated during chewing \\
\hline Umami & Soft to intense & Taste of glutamate, amino acid salts. Similar to soy sauce & \\
\hline Fat & Soft to intense & The aromas associated with animal fat when cooking & \\
\hline Methalic & Soft to intense & $\begin{array}{l}\text { The impression of flavor of rusty metal, such as iron, copper, } \\
\text { and silver spoons }\end{array}$ & \\
\hline \multicolumn{4}{|l|}{ Texture: } \\
\hline Firmness & Minor to mayor & Force required to penetrate the meat with the incisor teeth & Evaluated during chewing \\
\hline Fibrous & Minor to mayor & Quantification of fibers of the meat & \\
\hline Fat sensation & Soft to intense & Fat feeling in the mouth & \\
\hline Juiciness & Dry to juicy & The water perceived when the meat is chewed & \\
\hline
\end{tabular}


consumir carne de bovino más de dos veces a la semana, el $34 \%$ una vez a la semana, el $14 \%$ una vez cada 15 días, mientras que el $9 \%$ una vez al mes. Ellos refirieron que su forma de consumo habitual de carne era: asada, en hamburguesas y en guisos.

Desarrollo experimental. La prueba Dúo-trío(27), se realizó para determinar si las carnes sometidas a evaluación eran percibidas de manera similar por el consumidor. Se utilizaron dos tríadas ( $A-R E F A B$ y A-REF BA) donde $A$ correspondió a la muestra de carne (testigo), la cual se utilizó como referencia constante (REF) y B correspondió a la muestra de carne obtenida de los animales que consumieron taninos (ET). A los panelistas, se les presentaron tres muestras de carne, una de ellas marcada como muestra de referencia con la letra " $R$ ", mientras que las otras dos fueron codificadas con números aleatorios de tres dígitos. El panelista identificó cuál de las muestras era igual a R. Los resultados obtenidos, se analizaron de acuerdo a la Norma BS ISO 10399:2004. "Sensory analysis-Methodology-Duo-trio test"(27).

Las pruebas de preferencia por pares $(24,25)$, se realizaron para evaluar la jugosidad y la terneza. Las muestras de carne A (testigo) y B (ET), se codificaron con números de tres dígitos y se presentaron a los panelista de manera simultánea, en forma $A B$ para algunos y $B A$ para otros. El panelista identificó cuál de las dos muestras era la más suave y cuál la más jugosa. Los resultados se analizaron por la prueba de aproximación de la distribución binomial a la distribución normal $(\alpha / 2=0.025)$; $Z=(X-n p)-0.5 / \sqrt{ }$ npq, donde, $X=$ número de juicios de la muestra más preferida, $n=$ número total de juicios, $p=$ probabilidad de escoger la muestra más preferida de forma aleatoria y $q=1-p$, para prueba de comparación por pares $\mathrm{p}=\mathrm{q}=\frac{1}{2} 2(23)$.

La prueba afectiva $(24,25)$, se utilizó para evaluar la aceptación de la carne de bovinos alimentados con adición de extracto de taninos en la dieta.
Preference pairs tests $(24,25)$, were conducted to assess the juiciness and tenderness. Meat samples (control) and B (ET), were codified with three-digit numbers and were simultaneously presented to the panelist, in the form $A B$ for some and $B A$ for others. The panelist identified which one of the two samples was the softest and which the juiciest. The results were analyzed by the approximation test from the binomial distribution to the normal distribution $(\alpha / 2=0.025) ; Z=(X-n p)-0.5 / \sqrt{ } n p q$, where $X=$ number of trials of the most favorite sample, $n=$ total number of judgments, $p=$ probability of selecting the most favorite sample at random and $q=1-p$, for paired different test $p=q=1 / 2(23)$.

Affective testing $(24,25)$ was used to assess the acceptance of meat from fed-tannins cattle. Samples were presented in the same way as for the tests by paired test. The panelist assessed their preference on each sample according to a seven-point hedonic scale: 1) I dislike very much, 2) I dislike moderately 3) I dislike slightly, 4) Nor I like or I dislike, 5) I like slightly, 6) I like moderately, 7) I really like it. The results were transformed into numerical scale ( 1 to 7 ) in the same order. The frequencies were obtained and treatments were compared by level of acceptance using $X^{2}$ test, accepting statistical differences at $P<0.05(24,25)$. Statistical analyses were developed with version 9.0 of the computational Statistix package(18).

\section{RESULTS AND DISCUSSION}

The results of the physical characteristics are presented in Table 2. Addition of tannins had no effect on $\mathrm{pH}, \mathrm{WRC}$, cooking loss and shear force $(P>0.05)$. pH influences many biochemical and sensory properties of fresh and cooked meat, such as flavor and tenderness(28); the decrease in $\mathrm{pH}$ allows activation of proteolytic enzymes, and also allows proteins to reach their isoelectric point and therefore inducing a decrease of muscle water holding capacity $(2,28)$. The analyzed data showed a pH of 5.42 for 
Las muestras se presentaron de la misma forma que para las pruebas de comparación por pares. El panelista evaluó su preferencia sobre cada muestra de acuerdo a una escala hedónica de siete puntos: 1) me disgusta mucho, 2) me disgusta moderadamente, 3) me disgusta ligeramente, 4) ni me gusta ni me disgusta, 5) me gusta ligeramente, 6) me gusta moderadamente, 7) me gusta mucho. Los resultados, se transformaron a escala numérica ( 1 a 7) en el mismo orden. Se obtuvieron las frecuencias y se compararon los tratamientos por nivel de aceptación utilizando una prueba de $X^{2}$, aceptando diferencia estadística a $\mathrm{P}<0.05(24,25)$. Los análisis estadísticos se desarrollaron con la versión 9.0 del paquete computacional Statistix ${ }^{(18)}$.

\section{RESULTADOS Y DISCUSIÓN}

Los resultados de las características físicas se presentan en Cuadro 2. Se aprecia que la adición de taninos no influyó en el $\mathrm{pH}$, CRA, pérdida por cocción y fuerza de corte $(P>0.05)$. El pH influye en numerosas propiedades bioquímicas y sensoriales de la carne fresca y cocinada, tales como el sabor y la terneza(28), el descenso de $\mathrm{pH}$ permite que las enzimas proteolíticas se activen, así como también permite a las proteínas alcanzar su punto isoeléctrico y por consiguiente se induce la disminución de la capacidad de retención de agua del músculo $(2,28)$. Los datos analizados revelan un pH de 5.42 para ambos tratamientos, el cual está en el rango que se considera normal $(2,16)$.

Los resultados indicaron que la fuerza de corte fue superior a $8 \mathrm{kgf}$. De acuerdo a algunos investigadores (29-33), estos valores pueden estar influidos por factores tales como la raza, la alimentación, la edad y el manejo del animal. Otros investigadores $(29,30)$, han demostrado que la carne de Bos indicus es menos tierna que la de Bos Taurus; es importante recordar que la carga génica de los animales utilizados en este estudio fue en mayor proporción Brahman. Riley et al(30), reportaron valores superiores a $8 \mathrm{kgf}$ al evaluar la fuerza de corte en carne procedente both treatments, which is in the range considered as normal $(2,16)$.

Results indicated that the shear force was superior to $8 \mathrm{kgf}$. According to some researches(29-33), these values may be influenced by factors such as breed, feeding, age and animal handling. Others $(29,30)$, have shown that meat from Bos indicus is less tender than the meat from Bos taurus. It is important to remember that the gene load of animals used in this study was mainly from the Brahman breed. Riley et al(30), reported values greater than $8 \mathrm{kgf}$ from Brahman meat. It was also mentioned $(32,33)$ that the use of technologies to improve growth in feedlots (anabolic implants and B-adrenergic agonists) influence negatively the meat tenderness, so as the maturity of the animal, because the solubility of collagen decreases with increasing age and therefore favors the increase of meat shear force $(31,32)$. The value of shear force obtained in the experiment we are discussing it, could be due to the use of zilpaterol hydrochloride implants, coupled with maturity of animals in the finishing fattening stage.

Exp 1 results obtained for the sensory profile are shown in Figure 1. Tannins did not influenced the intensity of the attributes evaluated $(P>0.05)$. Taste and smell descriptors were

Cuadro 2. Influencia de la adición de extracto de taninos en las características físicas de la carne de bovinos alimentados de forma intensiva

Table 2. Influence of the addition of tannin extract in the physical characteristics of the meat of cattle fed intensively

\begin{tabular}{lcccc}
\hline & \multicolumn{2}{c}{ Treatments } & & \\
\cline { 2 - 3 } Variable & Control & Tannins & SEM & $P$ value \\
\hline $\mathrm{N}$ & 8 & 8 & & \\
$\mathrm{pH}$ & 5.42 & 5.42 & 0.023 & 0.88 \\
Water retention, \% & 87.32 & 86.21 & 1.058 & 0.48 \\
Cooking loss, \% & 32.47 & 30.04 & 1.589 & 0.30 \\
Shear force, kgf & 8.88 & 10.21 & 0.477 & 0.07 \\
\hline
\end{tabular}

$\mathrm{SEM}=$ standard error of the mean. 
de raza Brahman. También mencionan(32,33) que el uso de tecnologías para mejorar el crecimiento en corral de engorda (implantes anabólicos y agonistas ß-adrenérgicos) influyen de manera negativa en la terneza de la carne, así como también la madurez del animal afecta, ya que la solubilidad del colágeno disminuye con el aumento de la edad y por consiguiente favorece el incremento de la fuerza de corte de la carne $(31,32)$. El valor de fuerza de corte obtenido en el experimento que nos ocupa pudo deberse a que los animales recibieron implante y clorhidrato de zilpaterol; aunado a ello eran animales maduros en etapa de finalización de engorda.

Los resultados del Exp 1 obtenidos para el perfil sensorial se muestran en la Figura 1. Los taninos no influyeron en la intensidad de los atributos evaluados ( $P>0.05$ ). Los descriptores de sabor y olor se percibieron como suaves, lo que agrada al consumidor, ya que se ubican por debajo de la media de la escala. En otra investigación(34), se sugiere que el sabor en carne de res puede estar influenciado por el calor, la raza animal, el tiempo de envejecimiento, el tipo de músculo y la dieta; los componentes volátiles formados durante el cocinado de la carne son los que producen el atributo de olor, y contribuyen en las características de sabor de la carne $(28,34)$; cuando los bovinos son alimentados con dietas altas en granos, la carne presenta mayor palatabilidad y preferencia por los consumidores $(28,34)$. Los atributos, grasa, sensación grasa y jugosidad se percibieron como suaves, mientras que la firmeza y fibrosidad presentan valores altos. De acuerdo a algunas investigaciones $(2,3,5)$, el agua y la grasa influyen en la terneza de la carne; a menor cantidad de agua y de grasa, se percibe una carne con una menor jugosidad y menor sensación grasa, y por consiguiente la firmeza y la fibrosidad (atributos de terneza) se perciben altas.

El resultado del Exp 2 obtenido de la prueba Dúo-trío 100 (27), mostró que más del $75.0 \%$ de los consumidores considerarían similar la perceived as soft, pleasing to the consumer, since they were located below the average scale. Another study(34), suggests that the flavor in beef can be influenced by heat, animal breed, aging time, type of muscle and the diet; the volatile components formed during meat cooking are those that produce the smell attribute, and contribute to the meat taste characteristics $(28,34)$. When cattle are fed with high-grains diets, the meat has higher palatability and preference by consumers $(28,34)$. Attributes as fat, fat feeling and juiciness were perceived as soft, while the firmness and stringiness had high values. According to some research $(2,3,5)$, water and fat affect the meat tenderness; less amount of water and fat, feels a meat with a less juicy and smaller feel fat, and therefore firmness and the woodiness (attributes of tenderness) are high.

The results of the Exp 2 obtained by the Duotrio test, showed that more than the $75.0 \%$ of

Figura 1. Perfil sensorial de carne de bovino. $\mathrm{O}=$ olor; $\mathrm{T}=$ textura; $\mathrm{S}=$ sabor

Figure 1. Sensorial profile of the meat from bovine. $0=$ odor; $\mathrm{T}=$ texture; $\mathrm{S}=$ flavor

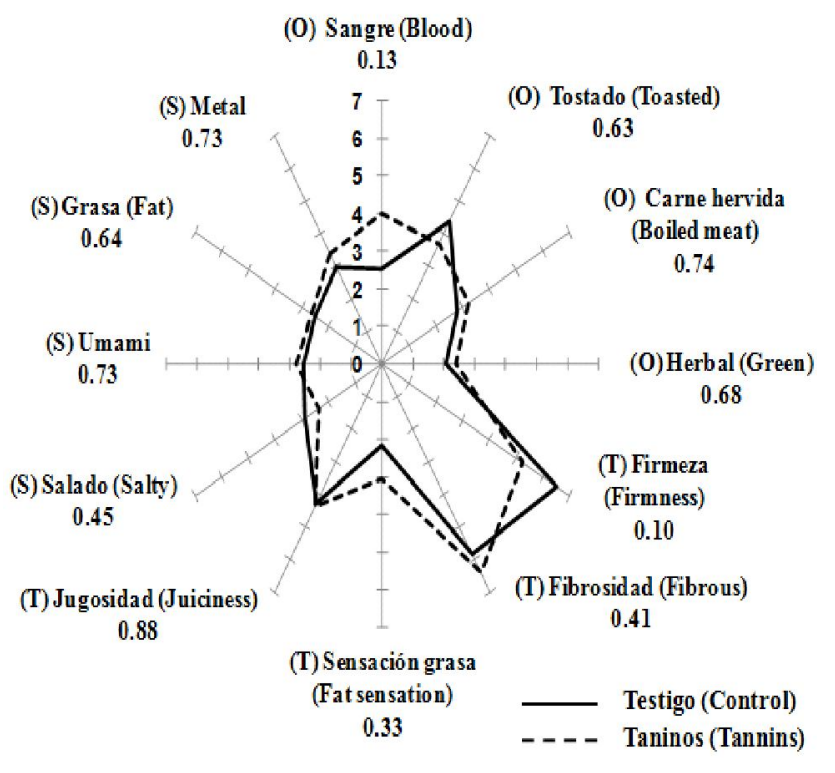

The number below descriptor name indicates the $P$-value in agreement with test of Wilcoxon $(\alpha<0.05)$ 
carne proveniente de bovinos alimentados con y sin adición de taninos en la dieta.

En la prueba de preferencia por pares, donde se evaluó la jugosidad de la carne, se obtuvo un valor de $z=0.03$. Para un $\alpha / 2=0.025$, al comparar con el valor de $z$ de tablas (1.96), muestra que los consumidores no perciben diferencias entre las muestras de carne. De igual forma al evaluar terneza el valor obtenido para $z=1.17$. Para un $\alpha / 2=0.025$, se observa que los consumidores no perciben un cambio en la terneza de la carne cuando los animales son alimentados con adición de extracto de taninos en la dieta.

Los resultados de la prueba de preferencia se muestran en Figura 2, se aprecia que el ítem de mayor aceptación de los consumidores para carne de bovino alimentados con y sin adición de taninos en la dieta fue para "me gusta moderadamente", donde el porcentaje de consumidores que prefirieron este nivel fue de $31.8 \%$ para carne sin taninos y $35.2 \%$ para carne con adición de taninos. Los resultados del análisis estadístico muestran que sólo en el ítem "me gusta mucho", se percibieron diferencias entre las muestras de carne $(P=0.02)$. Se aprecia que más del $74.4 \%$ de los consumidores declaró que le gustó la carne, a $14.7 \%$ le fue indistinto, mientras que $10.8 \%$ mostró algún disgusto.

Los resultados de las pruebas sensoriales muestran que la adición de $0.3 \%$ de extracto de taninos en la dieta de bovinos engordados de forma intensiva no influyen en la aceptación de la carne por parte del consumidor; con las características físicas que presentó esta carne (fuerza de corte aproximada de $9.5 \mathrm{kgf}$ ), se tiene una buena aceptabilidad, ya que más del $74.0 \%$ de los consumidores mostraron preferencia por ella.

\section{CONCLUSIONES E IMPLICACIONES}

El análisis sensorial mostró que al adicionar $0.3 \%$ de extracto de taninos en la dieta de consumers would consider a similar meat from cattle fed with and without addition of tannins in the diet. In the paired preference test, for meat juiciness, it was obtained a value of $z=0.03$, for $\alpha / 2=0.025$, and comparing with the z-value of tables (1.96), shows that consumers do not perceive differences between meat samples. Similarly, for assessing tenderness, the value obtained for $z=1.17$, for $\alpha / 2=0.025$, showed that consumers do not perceive a change in the meat tenderness when animals were fed with addition of tannin extract in the diet.

Preference test results in Figure 2, show that the item of greater acceptance of consumers to beef fed with and without addition of tannins in

Figura 2. Preferencia de los consumidores por la carne de bovinos alimentados con y sin adición de taninos en la dieta

Figure 2. Consumer preference for meat from cattle fed with and without addition of tannins in the diet

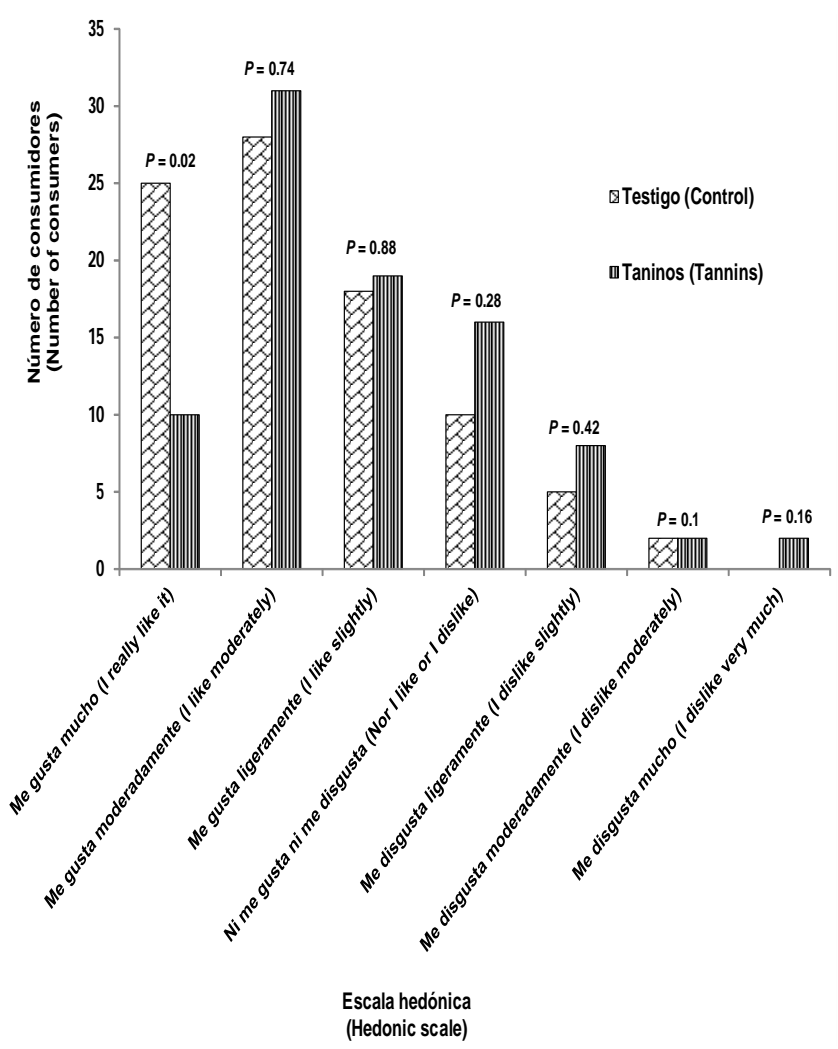


bovinos engordados de forma intensiva, no se perciben diferencias sensoriales al consumir la carne, ni provocan ningún cambio que sea perceptible por el consumidor. Lo anterior sugiere que bajas concentraciones de taninos pueden usarse como aditivos en dietas, sin riesgo de modificar las características físicas y sensoriales de la carne que provoquen atributos sensoriales inaceptables por el consumidor. En este estudio no se evaluó la presencia de taninos en carne, sin embargo, se considera prudente realizar esta medición, ya que con ello se podría discernir la duda de si los taninos se acumulan o no en tejido, y de ser positivo, conocer la concentración.

\section{AGRADECIMIENTOS}

Se agradece a la Dra. Isadora Martínez Arellano (UAM-Iztapalapa) su apoyo durante el proceso de esta investigación.

\section{LITERATURA CITADA}

1. Liria DMR. Guía para la evaluación sensorial de los alimentos http://www. slideshare.net/ evytaguevara/ gua-para-laevaluacin-sensorial-de-alimentos. 2007. Consultado 15 abril, 2014.

2. Lawrie RA, Ledward DA. Lawrie's meat science. 7th ed. Cambridge, England: Woodhead Publishing; 2006.

3. Bianchi. Alternativas tecnológicas para la producción de carne ovina de calidad en sistemas pastoriles. Montevideo, Uruguay: Hemisferio Sur; 2007.

4. Miller MF, Carr MA, Ramsey CB, Crockett KL, Hoover LC. Consumer thresholds for establishing the value of beef tenderness. J Anim Sci 2001; (79):3062-3068.

5. Rodas-González A, Huerta-Leidenz N, J erez-Timaure N, Miller MF. Establishing tenderness thresholds of Venezuelan beef steaks using consumer and trained sensory panels. Meat Sci 2009; (83):218-23.

6. Killinger KM, Calkins CR, Umberger WJ, Feuz DM, Eskridge $\mathrm{KM}$. Consumer sensory acceptance and value for beef steaks of similar tenderness, but differing in marbling level. J Anim Sci 2004; (82): 3288-3293.

7. Brewer PS, James JM, Calkins CR, Rasby RM, Klopfenstein TJ, Anderson RV. Carcass traits and M. Longissimus lumborum palatability attributes of calf- and yearling-finished steers J Anim Sci 2007; (85): 1239-1246.

8. Muchenje V, Dzam K, Chimonyo M, Strydom PE, Hugo A, Raats J G. Some biochemical aspects pertaining to beef eating the diet was for "I like moderately", where the percentage of consumers who preferred this level was $31.8 \%$ for meat without tannins and $35.2 \%$ for meat with addition of tannins. The results of statistical analysis show that only in the item "I like it very much", perceived differences between the meat samples $(P=$ 0.02 ). More than $74.4 \%$ of consumers stated that they liked the meat, $14.7 \%$ it was indistinct, while $10.8 \%$ showed some disappointment.

Sensory tests results show that the addition of $0.3 \%$ tannin extract in the diet do not influence the acceptance of meat by consumers; with physical characteristics that presented this meat (approximately 9.5 shear force kgf), has a good acceptability, because more than $74.0 \%$ of consumers showed preference for it.

\section{CONCLUSIONS AND IMPLICATIONS}

Sensory analysis showed that by adding $0.3 \%$ tannin extract in the diet of intensively fattened cattle, do not influence the acceptance of meat, nor cause any change that is detectable by the consumer. This suggests that low concentrations of tannins can be used as additives in diets, without the risk of modifying the physical and sensory meat characteristics causing unacceptable sensory attributes by the consumer. The presence of tannins in the meat was not evaluated in this study, however, it is considered prudent to perform this measurement, since it could help to discern the doubt if the tannins are accumulated or not in tissue, and if positive, to know the concentration.

\section{ACKNOWLEDGMENTS}

Thanks to Dra. Isadora Martínez Arellano (UAMIztapalapa) for support during the process of this investigation.

End of english version 
Briceida Ortiz-López, et al. / Rev Mex Cienc Pecu 2016; 7(3):309-320

quality and consumer health: A review. Food Chemistry 2009; (112): 279-289.

9. Benchaar C, McAllister TA, Chouinard PY. Digestion, ruminal fermentation, ciliate protozoal populations and milk production from dairy cows fed cinnamaldehyde, quebracho condensed tannin, or Yucca schidigera saponin extracts. J Dairy Sci 2008;91(12)4765-4777.

10. Frutos $P$, Raso $M$, Hervás $G$, Mantecón $A R$, Pérez $V$, Giráldez FJ. Is there any detrimental effect when a chestnut hydrolysable tannin extract is included in the diet of finishing lambs? Anim Res 2004;(53):127-136.

11. Makkar HP, Siddhuraju SP, Becker K. Plant secondary metabolites. Totowa, NJ: Human Press Inc; 2007.

12. Min BR, Pinchak WE, Anderson RC, Fulford JD, Puchala R. Effects of condensed tannins supplementation level on weight gain and in vitro and in vivo bloat precursors in steers grazing winter wheat. J Anim Sci 2006;(84):2546-2554.

13. Barajas R, Cervantes BJ, Camacho A, Velázquez EA, Espino $M A$, J uárez $F$, et al. Condensed tannins supplementation on feedlot performance of growing bulls [abstract]. J Anim Sci 2010:88(Suppl 2): 711.

14. Cañeque V, Sañudo C. Estandarización de las metodologías para evaluar la calidad del producto (animal vivo, canal, carne y grasa) en los rumiantes. Madrid, España: Monografías INIA: serie ganadera $\mathrm{N}^{\circ}$ 3. 2005.

15. AMSA. Research guidelines for cookery, sensory evaluation and instrumental tenderness measurements of fresh meat. Savoy IL American Meat Sci Ass. 1995.

16. González-Ríos H, Peña-Ramos A, Valenzuela M, ZamoranoGarcía L, Cumplido-Barbeitia G, González-Méndez NF HuertaLeidenz N. Comparison of physical, chemical, and sensorial characteristics between U.S.-Imported and Northwestern Mexico retail beef. J Food Sci 2010;(75):747-752.

17. Steel RGD, Torrie JH. Bioestadística: principios y procedimientos. 2da ed. México DF: McGraw-Hill/ interamericana de México; 1988.

18. Statistix. Statistic User's Manual. Release 9.0 Analytical Software, Tallahassee, FL. 2007.

19. ISO 8586:2012. Sensory analysis - General guidelines for the selection, training and monitoring of selected assessors and expert sensory assessors. 2012.

20. Martínez Al, Severiano PP, Fernández Fl, Ponce AE. Changes in the physicochemical and sensory characteristics in raw and grilled ovine meat. J Sci Food Agric 2012; (93):1743-1750.

21. Adhikari K, Chambers IVE, Miller R, Vázquez-araújo L, Bhumiratana N, Philip C. Development of lexicon for beef flavor in intact muscle. J Sens Stud 2011;(26):413-420.
22. Escalona BHB, Domínguez GM, García RMI, Ponce AE. Indicadores sensoriales de calidad en la cadena de producción de carne fresca de res y cerdo de México. XIV Congreso Nacional de Biotecnología y Bioingeniería. http:/ /www.smbb.com. mx/congresos\%20smbb/queretaro11/ TRABAJ OS/trabajos/III/carteles/CIII-86.pdf. 2011. Consultado 20 abril, 2014.

23. Pérez ML, Escalona H, Guerrero I. Effect of calcium choride marination on calpain and quality characteristics of meat from chicken, horse, cattle and rabbit. Meat Sci 1998; (48): 125-134.

24. O'Mahony M. Sensory evaluation of food statistical methods and procedures. New York, USA: Taylor \& Francis; 1986.

25. Stone $H$, Sidel J. Sensory evaluation practices. $3^{\text {rd }}$ ed. San Diego California, USA: Elsevier Academic Press; 2004.

26. Wayne WD. Bioestadística base para el análisis de las ciencias de la salud. 4ta ed. México DF: Limusa, SA de CV; 2004.

27. BS ISO 10399:2004. Sensory analysis-Methodology-Duo-trio test. 2004.

28. Brewer MS. The chemistry of beef flavor -Executive summary. Centennial, CO. Illinois, USA. National Cattlemen's Beef Association. 2006

29. J ohnson MH, Calkins CR, Huffman RD, J ohnson DD, Hargrove DD. Differences in cathepsin $B+L$ and calcium dependent protease activities among breed type and their relationship to beef tenderness. J Anim Sci 1990;(68):2371-2379.

30. Riley DG, Chase CC, Jr, Pringle TD, West RL, Johnson DD, Olson TA, et al. Effect of sire on $\mathrm{m}$ - and m-calpain activity and rate of tenderization as indicated by myofibril fragmentation indices of steaks from Brahman cattle. J Anim Sci 2003; (81):2440-2447.

31. Schereus NM, García F, J urie C, Agabriel J, Micol D, Bauchart $D$, et al. Meta-analysis of the effect of animal maturity on muscle characteristics in different muscles, breeds, and sexes of cattle. J Anim Sci 2008; (86):2872-2887.

32. Howard ST. Beef tenderness and the management of calffed Holstein steers to meet market standards [doctoral thesis]. Colorado, USA: Colorado State University; 2013.

33. Garmyn AJ, Miller MF. Meat science and muscle biology symposium-Implant and beta agonist impacts on beef palatability. J Anim Sci 2014;(92):10-20.

34. Tansawat R. Chemical characterization of meat related to animal diet. [All Graduate Theses and Dissertations]. http:/ /digitalcommons.usu. edu/etd/1339. 2012. Accessed Dec 12, 2014. 